\title{
ORGANISASI SEKOLAH YANG VISIONER
}

\author{
Muh. Hambali ${ }^{1}$
}

\begin{abstract}
School organization is an institution that manages aspects of knowledge, attitude, and skills of students. The organization not only has responsible about learning, but also responsible about condition of school that encourage changes in how to manage the headmaster. Headmaster is the main driver of school organization. To be visionary school organization needs the characteristic of organization both of mechanic and organic. Headmaster needs strong capacity to encourage the organization to achieve dynamic tradition and competency at school. That condition has impacts towards structure and culture at school that can respond to the expectation and challenges in the future.

Headmasters who have visionary leadership can manage challenge to be expectation to achieve the goal of school. Besides that, headmaster tries to inspire the stakeholders to be the center of changes every time in order to adapt to technological developments and the needs of industrial society. School organization reflects the combination between individuals who have the same dream. The duty of headmaster is realizing the expectations of vision and mission of school. Headmaster showed the visionary characteristic in managing the elementary school organization.
\end{abstract}

Keywords: School Organization, Visionary

\section{A. Pendahuluan}

Organisasi sekolah mencerminkan gabungan individu yang terdiridari dua orang atau lebih yang berkumpul dalam setiap kelompok untuk mewujudkan visi. Inti organisasi sekolah mempunyai struktur yang bertugas untuk membagi kinerja adalah pemimpin sekolah. Tugas kepemimpinan adalah mewujudkan harapan-harapan visi organisasi sekolah dan untuk mengerjakan tujuan bersama (Yukl, 1981: 7). Oleh sebab itu, kepemimpinan adalah menetapkan arah yang dapat dirasakan (a sensible direction), membuat orang-orang menyelaraskan diri ke arah itu, dan memberi mereka kekuatan (energizing them) untuk mencapainya dengan cara-cara yang terencana (John P. Kotter, 1994). Kepemimpinan

1 Dosen Fakultas Ilmu Tarbiyah Dan Keguruan Universitas Islam Negeri Maulana Malik Ibrahim Malang Jl. Gajayana No. 50 Malang 65144 
adalah mempengaruhi orang lain dan membangun inovasi-inovasi secara langsung di dalam organisasi (R.M. Steers, G.R. Ungson, R.T. Mowday, 1985: 3007). Senada pendapat Kasali bahwa pemimpin mesti dapat menjadi motivator, coach, penerjemah, nabi, dai, guru, paus, jenderal, atau panglima (Rhenald Kasali, 2007: 128).

Setiap organisasi sekolah membangun tahapan kinerja untuk mencapai visi kelembagaan. Organisasi sekolah yang mengabaikan visi terletak pada masalah ideologis dan kerja-kerja sporadis berdampak pada lemahnya visi kelembagaan. Menurut Beach bahwa bervisi tidak dibatasi hanya investigasi secara alamiah, tetapi menginspirasi kejiwaan, fantasi, dan intuisi, memberanikan penjelasan, sasaran, dan memperkuat keyakinan terhadap sasaran yang dicapai. Jadi, organisasi sekolah yang memiliki visi membutuhkan pemimpin yang dapat mengartikulasi visi yang dapat menghasilkan harapan kelembagaan. Pemimpin yang memiliki visi menurut Robbin adalah Visionary leadership is the ability to create and articulate a realistic, credible, attractive vision of the future for an organization or organizational unit that grows out of and improves upon the present (Robbins, 1996: 375).

Miniatur visi kelembagaan adalah terlihat dari pemimpin sekolah meneguhkan antara kata dan perbuatan secara harmoni. Keteguhan itu juga usaha terus-menerus untuk mewujudkan harapan dan mengelola tantangan menjadi peluang organisasi sekolah. Keteguhan itu dapat disebut pemimpin yang mempunyai integritas. Integritas mengandung unsur terbuka, jujur, toleran, percaya diri, peduli, dan komitmen pada tradisi masa lalu yang terbaik (Nanus, 1998: 81-87). Integritas adalah konsistensi antara nilai dan tindakan. Pemimpin yang memiliki integritas sejalan dengan nilai-nilai prinsipnya. Integritas pemimpin ditandai dari cara membangun komitmen kepada para guru dan para pegawai dalam mencapai kemampuan prestasi warga sekolah dalam rangka memiliki unggulan dan mempengaruhi persepsi masyarakat (Yukl, 1981: 9).

Organisasi merupakan sistem sosial yang mempunyai pola kerja yang teratur yang didirikan oleh individu-individu dalam kelompok untuk mencapai satu persepsi tujuan tertentu. Tujuan-tujuan organisasi yang sudah terwujudkan dapat diobservasi pada aspek artefak. Artefak merupakan eleman budaya yang kasat mata dan diibaratkan seperti lava panas/dingin yang keluar dari perut bumi mengindikasikan di dalamnya aktivitas yang tidak nampak dari luar. Kategori artefak 
dibagi menjadi tiga hal, yaitu manifestasi fisik, manifestasi perilaku dan manifestasi verbal (Hatch, 1997: 216) .

\section{Tabel Artefak}

\begin{tabular}{|l|ll|}
\hline \multicolumn{1}{|c|}{ Kategori umum } & \multicolumn{2}{|c|}{ Contoh artefak } \\
\hline Manifestasi fisik & 1. & Seni/design/logo \\
& 2. & Bentuk bangunan \\
& 3. & Personifikasi seseorang \\
& 4. & Tata letak bangunan \\
& 5. & Desain organisasi \\
\hline Manifestasi perilaku & 1. & Ceremonial \\
& 2. & Cara berkomunikasi \\
& 3. & Tradisi \\
\hline Manifestasi verbal & 4. & Sistem reward \\
& 1. & Anekdot atau humor \\
& 2. & Jargon/cara menyapa \\
& 3. & Mitos/sejarah/cerita sukses \\
& 4. & Orang2 yg dipersepsikan pahlawan \\
& 5. & Metafora yg digunakan \\
\hline
\end{tabular}

Taksonomi artefak di atas dapat diobservasi pada organisasi sekolah berdasarkan penulis lakukan di SD Unggulan Al-Ya'lu Malang dan SDI Alam Bilingual Surya Buana Malang. Fenomenanya adalah pemimpin sering mengungkap kalimat menjadi sekolah unggulan dari yang sudah unggul kepada setiap guru dan pegawai. Kalimat itu diadaptasi dari visi SD yang berasal dari visi sekolah "menjadi lembaga pendidikan yang unggul di era global" (www.al-yaklu.com). Visi Keunggulan itu mampu menjiwai seluruh warga sekolah, namun kepala sekolah selaku pemimpin menginternalisasi dalam diri terlebih dahulu dan menunjukkan keunggulan-keunggulan dalam bentuk prestasi guru. Kepemimpinan memperoleh hasil sesuai visi manakala memulainya dari keteladan. Hal dikuatkan dari nilai-nilai keteladan yang pernah tersurat dalam sejarah hijrah Nabi Muhammad SAW (Antonio, 2007: $67)$. 
Artefak lainnya adalah wajah penampilan pendidik yang profesional, wajah penampilan pegawai administrasi yang profesional. Keunggulan tersebut berimplikasi kepada keberhasilan prestasi guru dan prestasi siswa baik di tingkat lokal maupun nasional. Prestasinya sekolah ditunjukkan pemimpin sekolah melalui personal computer (PC) miliknya yang sudah tersambung dengan jaringan internet sekolah secara on line dan membuka website SD Al-Ya'lu. Salah satu yang ditunjukkan kepala sekolah adalah internalisasi nilai-nilai keteladanan selaku guru yang berusaha menunjukkan keunggulan dalam membuat karya-karya ilmiah berupa buku ajar. Buku ajar yang telah mendapatkan kategori terbaik dari Pusat Perbukuan Nasional di Jakarta. Buku lainnya adalah buku pengkayaan untuk menunjang mata pelajaran pendidikan kewarganegaraan kelas II mendapatkan juara tiga tingkat nasional dari Pusat Perbukuan Nasional di Jakarta pada November 2009.

Kepercayaan masyarakat mengalami peningkatan untuk mendaftarkan peserta didik di SD Unggulan Al-Ya'lu Malang meskipun relatif baru berdirinya. Pendaftar di SD tersebut adalah enam puluh siswa yang terbagi menjadi tiga kelas yang setiap kelas berjumlah dua puluh siswa. Perubahan peningkatan jumlah dari sembilan siswa menjadi enam puluh siswa adalah kepercayaan yang telah diberikan masyarakat. Sekolah ini merupakan peserta baru dalam ujian nasional telah menunjukkan perkembangan nilai rata-rata terbaik di Kota Malang pada tahun 2009.

Sebagaimana juga SDI Alam Bilingual Surya Buana Malang visinya adalah unggul dalam prestasi, terdepan dalam inovasi, dan maju dalam kreasi untuk membentuk insan berakhlakul karimah. Visi ini menginspirasi warga sekolah untuk berusaha terus-menerus dalam mengembangkan tradisi-tradisi unggulan sekolah. Hal itu telah ditunjukkan seorang guru kelas dalam membuat alat peraga pembelajaran yang mendapatkan prestasi juara I tingkat nasional yang diselenggarakan oleh PT Kraf Biskuit bekerjasama dengan pendidikan nasional pusat Jakarta tahun 2008.

Tujuan organisasi dapat dipengaruhi oleh sikap dan cara pandang para warga sekolah dalam mengartikulasi visi sekolah. Salah satu guru dapat menterjemahkan dan dapat membangun tradisi berkarya. Hal ini menginspirasi untuk menunjukkan profesi guru. Domain ini dipengaruhi oleh sebuah nilai. Sebagaimana Quiley memandang nilai 
adalah keyakinan yang mendasar dalam organisasi (Quiley, 1993: 97). Nilai itu mempunyai pengaruh pada seorang pemimpin dalam menggerakkan organisasi, nilai itu mengenai apa yang sebenarnya dipengaruhi oleh nilai, dan nilai itu mempunyai pengertian adanya tata tingkat preferensi nilai terhadap modul perilaku kepemimpinan. Nilai mempunyai fungsi sebagai penggerak aktivitas masyarakat dan menjiwai semangat mewakafkan diri ke lembaga. Nilai-nilai organisasi merupakan prinsip operasional dan arahan untuk mencapai visi dan misi organisasi yang mampu mengekpresikan keyakinan dan aspirasi lembaga (Sallis, 1993: 97).

Misi adalah implementasi visi yang merupakan hasil pemikiran seseorang, pemimpin, dan lembaga yang meliputi pertanyaan, bersedia menjadi lembaga yang diharapkan oleh kepemimpinan yang tergambar dalam visi. Pemimpin sekolah menjalankan misi beserta dengan warga sekolah merupakan wujud mengawal visi dan misi agar sesuai dengan harapan bersama. Sedangkan tujuannya merupakan arah ke mana organisasi dibawa yang meliputi pertanyaan, bersedia menghasilkan apa, untuk siapa, dan keunggulan perlu ditunjukkan dari hasil tujuan pendidikan.

Setiap organisasi sekolah mampu mendorong warganya dalam penjiwaan nilai-nilai itu berdampak pada perbuatan kebaikan dan kerja-kerja kolektif yang didorong oleh keteladanan pemimpin sekolah dan tradisi kegiatan keagamaan.. Pesan tersirat dalam Al-Qu'an surat Al-'Ashr, ayat 3"

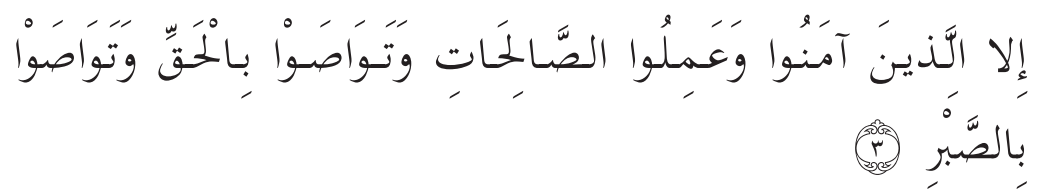

Artinya : "Kecuali orang-orang yang beriman dan mengerjakan amal saleh dan nasehat menasehati supaya mentaati kebenaran dan nasehat menasehati supaya menetapi kesabaran." 


\section{B. Kontruksi organisasi Sekolah dalam Pengambangan Visioner Kelembagaan}

\section{Karakteristik Kepala Sekolah berjiwa Leader dan Manajer}

Dalam Islam,. Kedudukan kepemimpinan mempunyai posisi penting pada setiap organisasi sekolah. Sebagaimana Hadits Nabi Muhammad SAW yang artinya dari Abu Said dari Abu Hurairah bahwa keduanya berkata, Rasulullah bersabda, Apabila tiga orang keluar bepergian, hendaklah mereka menjadikan salah satu sebagai pemimpin (HR. Abu Dawud).

Islam menempatkan pemimpin menjadi penentu perubahan organisasi sekolah. Kepemimpinan memperhatikan standar visi, misi, dan tujuan sekolah agar tercapai kualitas pendidikan. Ini memberikan tempat dinamika pemimpin berinisiatif di lingkungan sekolah dalam pengembangan lembaga (Pidarta, 1995: 81). Penegasan itu tertera pada Surat Al-Baqarah:30 berikut ini

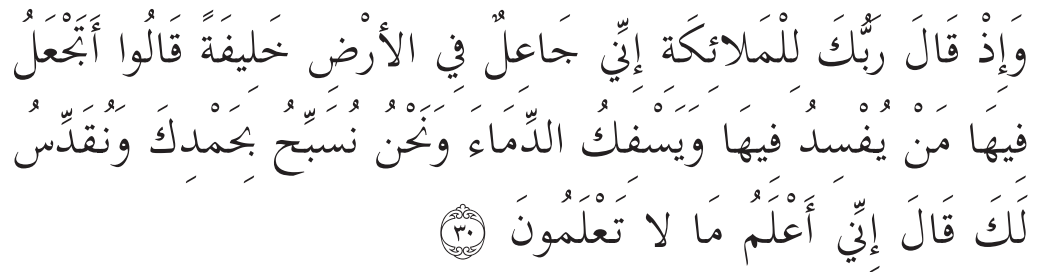

Artinya : "Ingatlah ketika Tuhanmu berfirman kepada Para Malaikat: «Sesungguhnya aku hendak menjadikan seorang khalifah di muka bumi.» mereka berkata: «Mengapa Engkau hendak menjadikan (khalifah) di bumi itu orang yang akan membuat kerusakan padanya dan menumpahkan darah, Padahal Kami Senantiasa bertasbih dengan memuji Engkau dan mensucikan Engkau?» Tuhan berfirman: «Sesungguhnya aku mengetahui apa yang tidak kamu ketahui."

Menurut Nanus, pemimpin visioner memiliki empat peran yang harus dijalankan dalam melaksanakan kepemimpinannya, yaitu: Pertama, peran penentu arah (direction setter) adalah menyajikan suatu visi, meyakinkan target untuk suatu organisasi, guna diraih pada masa depan, dan melibatkan orang-orang. Kedua, agen perubahan (agent of change). Agen perubahan merupakan peran penting kedua dari seorang pemimpin visioner. Ketiga, juru bicara (spokesperson). Memperoleh pesan ke luar, dan juga berbicara, boleh dikatakan merupakan suatu 
bagian penting dari memimpikan masa depan suatu organisasi.. Keempat, pelatih (coach)adalah melatih yang baik dalam menggunakan kerjasama kelompok untuk mencapai visi yang dinyatakan (Nanus, 2001: 15-18).

Manurut Harefa (2000:19), visioner adalah suatu ketidakpuasan yang mendalam mengenai realitas faktual masa kini yang dibarengi dengan suatu pandangan yang tajam mengenai kemungkinan menciptakan realitas baru di masa depan, yang secara mendasar lebih baik. Visioner memiliki penekanan pada ketidakpuasan terhadap realitas faktul masa kini yang mencakup, yaitu 1) adanya pemahaman mengenai konteks, situasi, dan kondisi nyata, kebagaimanaan masa kini; 2) pemahaman itu berdasarkan fakta-fakta empiris dan data-data;3) Pemahaman itu menimbulkan constructive discontent. Artinya bentuk ketidakpuasan tidak dirasuki oleh dendam dan sakit hati, tetapi lebih oleh kesadaran terhadap besarnya potensi yang belum teraktualisasikan dengan baik.

Menurut Yukl, kepemimpinan adalah mengartikulasikan visi, mewujudkan nilai-nilai dan meciptakan lingkungan sekolah dapat berprestasi. Kepemimpinan adalah kemampuan individu untuk mempengaruhi motivasi yang dapat memberikan kontribusi terhadap efektivitas dan mensukseskan organisasi (Yukl, 2002: 3). Sebagaimana pendapat Kenneth Blanchard adalah The key successful leadership today is influence, not authority. Pendapat tersebut dikutip oleh Kasali. Pendapatnya adalah kepemimpinan ditandai oleh kemampuan kepala sekolah melakukan perubahan peningkatan mutu lembaga berdasarkan cara mempengaruhi persepsi masyarakat (Kasali, 2007: 17).

Kepemimpinan dianjurkan bersifat autentik: jujur baik kepada individu dan kelompok. Agar dapat jujur kepada diri manusia, penulis perlu memperhatikan setiap ketidak-selarasan yang ada antara metafora yang penulis diakui dan perilaku yang dituntut oleh metafora itu. Jadi, jika isu yang dihadapi oleh rasisme, maka tantangan awal bagi kepemimpinan adalah mengandung supremacist untuk menjamin suatu tempat bagi semua, mengundang pembebas untuk memberdayakan partisipasi bagi semua, mengandung pelaku perjalanan untuk memperhatikan semua, mengandung pencipta untuk mengambil tanggung jawab atas semua (Terry, 2002: 266).

Namun demikian, ada kesamaan dalam mendefinisikan kepemimpinan, yakni mengandung makna memengaruhi orang lain 
untuk berbuat seperti yang pemimpin kehendaki. Jadi, kepemimpinan adalah ilmu dan seni menggerakkan dan mempengaruhi organisasi untuk bertindak sesuai visi, misi, dan tujuan lembaga pendidikan. Senada pendapat William Cohen (1990), kepemimpinan adalah seni mempengaruhi orang lain untuk melakukan unjuk kerja maksimum guna menyelesaikan suatu tugas, mencapai suatu tujuan atau menyelesaikan sebuah proyek.

Kepemimpinan diri mempunyai makna menegakkan disiplin atas diri pribadi (self discipline.) Hal ini merupakan aktivitas yang paling berat karena berkaitan dengan diri sendiri dan tidak melibatkan orang lain. Kepemimpinan yang efektif sangat ditentukan oleh kualitas diri dalam mengelolanya. Kepemimpinan merupakan peristiwa sosialisasi diri dalam suatu organisasi. Suatu organisasi memiliki kekuatan dan kelemahan. Kepala sekolah bertugas memaksimalkan kekuatan yang dimiliki organisasi dalam menggerakkan sistem yang berlaku. Kepemimpinan organisasi sekolah akan mendapatkan koreksi dari orang lain jika berbuat salah.

Pemimpin memfokuskan pada kegiatan, perubahan dan proses kelompok (Bass. 1981: 7). Pemimpin memiliki posisi khusus sebagai agen utama dalam menetapkan struktur, iklim, tujuan, ideologi, kegiatan kelompok, dan karakteristik budaya organisasi sekolah. Perubahan-perubahan organisasi sekolah terjadi adanya kepemimpinan. Kepemimpinan merupakan kerja bersama-sama yang dilakukan oleh seluruh individu dalam organisasi yang berbasis mekanisme kerja yang berlaku di organisasi.

Organisasi sekolah mengalami perubahan-perubahan ke arah lebih baik dari sebelumnya jika pemimpin mengembangkan daya pikir besar, berorientasi ke depan, dan bersifat jangka panjang. Sebagaimana pemikiran Kasali bahwa visioner mempunyai arti berpikir besar dan baru (think big and new) dan berpikir imajinasi (Think imaginative) (Khasali, 2007: 138). Ini artinya bahwa visioner menjelaskan, yaitu 1) kemampuan membuka pagar batas organisasi, agar lebih banyak jendela, 2) kemampuan memberi multi perspektif melalui perjalanan inspiratif, pencerahan-pencerahan, 3) pelatihan-pelatihan terbuka, memberi ruang interaktif dengan dunia luar.

Gagasan-gagasan di atas memandu terwujudnya organisasi sekolah yang terbuka dan dinamis. Sekolah sebagai organisasi pengembangan 
ilmu pengetahuan dan ilmu terapan kepada peserta didik tidak dapat mensejajarkan dalam pengelolaaan. Pengelolaan organisasi sekolah mestinya berbeda dari organisasi lain karena karakteristiknya berbeda, sekolah bukan sekedar tempat berkumpul para warga sekolah, namun lebih dari itu sebagai pusat pengembagan emosi dan intelektual peserta didik. Ini artinya sekolah membutuhkan seorang kepala sekolah yang memiliki karakteristik leader dan manajer. Karakteristik ini dapat dipaparkan berikut ini.

\section{Tabel : Karakteristik Leader dan Karakteristik Manager}

\begin{tabular}{|c|c|}
\hline Leader & Manager \\
\hline Vision & Plan \\
\hline Inspiratif & Reward \\
\hline Empower & Direct \\
\hline Coach & Train \\
\hline Revenues & Expenses \\
\hline Forecasts & Budgets \\
\hline Possibilities & $\begin{array}{c}\text { Systems and } \\
\text { Procedures }\end{array}$ \\
\hline Opportunity & Schedule \\
\hline Synergy & Coordinate \\
\hline
\end{tabular}

Bennis (1995: 6) membedakan karakteristik antara leader dan manajer. Dua istilah tersebut akan lebih baik terintegrasi dalam kepemimpinan organisasi sekolah. Organisasi sekolah tidak hanya membutuhkan karakteristik pemimpin, oranisasi sekolah juga membutuhkan karakteristik manager. Menurutnya adalah

"Leaders are people who do the right things and managers are people who do things right. Leaders are intersted in direction, vision, goals, objectives, intention, purpose, and effectiveness - the right thing. Managers are intersted in efeciency, the how - to, the day, to - day, the short run of doing things right". 
Karakteristik leader kecenderungan berpikir jangka panjang dalam mencapai tujuan. Ini artinya relevan dengan kepemimpinan sekolah bersifat jangka panjang, bersifat visioner. Pemimpin tanpa memiliki visioner adalah pemimpin yang reaktif. Pemimpin yang memiliki sifat reaktif berdampak bekerja cepat merespons semua tindakan, tetapi hasilnya tidak efektif. Ia hanya berorientasi pada segala hal yang kasat mata, yaitu di sini dan saat ini. Pemimpin yang visioner juga mengedepankan pengelolaan organisasi berdasarkan rencana-rencana yang bersifat baru dan dinamis.

Karakteristik leader adalah memiliki visi yang mampu memandu dalam mengelola organisasi pendidikan secara terus-menerus. Visioner menghadirkan dunia makna mimpi masa depan yang perlu direspon agar impian-impian lembaga dapat diwujudkan. Visioner dapat memberikan inspirasi, menggugah emosi, membangkitkan antusiasme, dan menyuntikkan motivasi. Motivasi inidividu maupun kelompok dapat menimbulkan sense of direction, menunjukkan arah yang perlu ditempuh.

Sebaliknya karakteristik manajer yang mengedepankan menjaga stabilitas kinerja organisasi. Kebutuhan organisasi sekolah adalah adanya keteraturan dalam distribusi peran kepala sekolah secara efektif dan efisien. Kepala sekolah adalah pengelola keteraturan dan sinergi antara unit-unit dalam kelembagaan. Setiap kelembagaan memiliki ruang lingkup pekerjaan dan tenaga sumber daya yang berbeda-beda. Hal ini berdampak pada urgennya kepala sekolah yang mempunyai ketrampilan pengelolaan. Warga sekolah melakukan kinerja berbasis wilayah pekerjaan yang sudah terstruktur. Kinerja warga sekolah bertugas sesuai dengan bidang spesifikasi kompetensi dan kepala sekolah memberikan penghargaan kepada warga sekolah berdasarkan kriteria-kreteria tertentu.

\section{Pengelolaan organisasi sekolah}

Fenomena organisasi sekolah tidaklah semata sebuah struktur yang membagi wilayah pekerjaan dan pemimpin sekolah berbasis pengalaman. Organisasi sekolah yang memiliki keduanya tersebut belum menjamin perubahan yang ideal. Perubahan mesti untuk mengubah cara manusia berpikir dan mengubah cara bertindak untuk membentuk kesamaan dalam melihat sesuatu yang baru, membentuk kenyataan yang baru 
dan menerimanya sebagai kebenaran. Keterbatasan pengetahuan dan pengalaman menyebabkan setiap manusia kembali berpikir pada cara lama.

Ketika organisasi sekolah tidak mengalami perubahan, maka membutuhkan budaya korporat. Budaya ini adalah suatu sistem nilai yang membimbing orang-orang pada suatu institusi untuk berperilaku tertentu. Organisasi ini memiliki perbedaan dengan organisasi paguyuban dan keluarga. Organisasi ini memiliki delapan karakteristik spirit korporatisasi (Khasali, 2007: 154), yaitu

1. Pemisahan kekayaan (antara milik individu/keluarga/kelompok dengan milik organisasi sebagai badan hukum).

2. Pemisahan tanggung jawab, antara pemilik dan manajemen.

3. Mengutamakan kepentingan pelanggan (costumer satisfaction).

4. Bekerja dengan sistem.

5. Adanya pencatatan dan transparasi.

6. Adanya pertanggungjawaban (accountability)

7. Bergerak dengan strategi dan rencana kerja.

8. Adanya upaya regenerasi berkelanjutan.

Uraian di atas mengandung sistem nilai korporasi yang relevan dengan ketentuan hukum. Korporatisasi mempunyai syarat dalam penerapan di organisasi sekolah. Ini artinya adalah manusia bersedia mensetujui kesepakatan melakukan pemisahan antara apa yang ia miliki dan apa yang harus menjadi milik organisasi. Hal ini berdampak pada organisasi harus memiliki kekayaan sendiri yang tidak munkin menyatu dengan milik pendiri organisasi sekolah.

Budaya korporat mengedepankan sistem nilai untuk memandu personifikasi organisasi. Sistem nilai itu adalah sistem nilai inovatif dan sistem nilai kreatif yang dapat mendorong warga sekolah berprestasi. Budaya korporat merupakan sebuah strategi, bukan sebuah budaya antropologis atau sejarah, melainkan budaya yang dibentuk untuk beradaptasi dengan kebutuhan masyarakat saat ini.

Budaya korporat dipengaruhi oleh nilai-nilai para pendiri organisasi. Namun yang terpenting adalah budaya inklusif dan nilai yang mencerminkan kemampuan organisasi beradaptasi dengan lingkungannya. 
Seperti orang tua yang menanamkan nilai-nilai pada anaknya, organisasi sekolah menanamkan nilai-nilai warga sekolah agar ia menjadi anak yang baik saja, melainkan juga nilai-nilai yang diperlukan untuk menghadapi kompetensi atau keadaan yang berubah-ubah. Misalnya daya kreasi, inisiatif, bekerja sama, kecepatan merespons, dan sebagainya.

Nilai itu tidak hanya berada pada wilayah dassolen (ide), melainkan pada wilayah das sein (nyata) yang dapat ditanam dan diberi pupuk yang bersifat operasional. Nilai-nilai itu ditanam kepada semua orang, sejak mereka bergabung. Ia diberi pupuk melalui kegiatan studi lapangan, keteladan pemimpin organisasi sekolah, rekrutmen, logo dan tulisan atribut lembaga serta bukti-bukti nyata yang menyangkut penegakkan disiplin, tradisi kompetisi, penghargaan, kegiatan sosial dan berdasarkan SOP (standard operating procedur) ataupun tata tertib organisasi sekolah.

Setiap organisasi sekolah membutuhkan standarisasi agar dapat mengukur setiap adanya perubahan. Standarisasi perubahan terletak pada dua aspek berikut ini (Khasali, 2007: 158 dan 161).

1. Reorientasi OCEAN (Openness to experience, Consciousness, Agreebleness, Neuroticism)

Menumbuhkan sikap-sikap positif dalam pembaharuan, yaitu keterbukaan terhadap hal-hal baru, penanaman nilai-nilai kedisiplinan, etos kerja dan kreativitas. Keterbukaan terhadap diri, keterbukaan terhadap kesepakatan dan keterbukaan terhadap tekanan diri.

2. Re-desain organisasi

Karakteristik kepemimpinan kepala sekolah membutuhkan disain secara terencana dan menggambarkan karakteristik organisasi yang terbuka dan dinamis. Setiap organisasi perlu menggambarkan aspek struktur, keterkaitan-keterkaitan (linkages), batas-batas (boundary), sistem insentif, dan nuansa/iklim. Batas-batas ruang lingkup organisasi itu perlu didukung oleh organisasi organik ataupun organisasi mekanik.

1) Ciri-ciri organisasi organik adalah
- Alat kontrol
kekerabatan
- Struktu
team work 
- Tuntutan

- Sifat pekerjaan

- Lingkungan kreativitas

berubah-ubah

Dinamis

2) Ciri-ciri organisasi mekanik adalah

- Alat kontrol

- Struktur

- Tuntutan

- Sifat pekerjaan

- Lingkungan prosedur

birokratik

kepatuhan

rutin

stabil

Sebuah organisasi sekolah mempunyai karakteristik beragam sangat tergantung visi dan misi pendirian organisasi sekolah. Suatu organisasi sekolah mempunyai relasi dengan dengan instansi pemerintah atau non pemerintah. Setiap organisasi sekolah semestinya tidak hanya berpijak pada prosedur kegiatan organisasi dan rutinitas kerja, namun membutuhkan komunikasi yang kekerabatan dan pola kerja yang dinamis. Organisasi sekolah merupakan wadah pengembagan sumberdaya manusia yang seharusnya memiliki kedua ciri di atas agar dapat meningkatkan kualitas peserta didik. Tanggung jawab kepala sekolah adalah menstimulus pengembangan organisasi sekolah. Setiap organisasi sekolah menghadapi realitas internal sekolah dan eksternal sekolah. Dua realitas tersebut menjadi pokok pemikiran dan kebijakan bagi kepala sekolah yang memiliki karakteristik leader dan manager. Dua istilah tersebut membutuhkan integrasi dalam pelaksanaan di sekolah (Muh. Hambali, 2012:21). Sekolah merupakan unit sosial yang membutuhkan partisipasi seluruh warga sekolah.

Setiap kepala sekolah mesti memahami terhadap dua realitas di atas agar tidak terjebak pada karaktersitik organisasi mekanik yang sangat lemah terhadap perubahan. Perubahan organisasi sekolah jika kepala sekolah mampu membaca peluang ke depan dengan syarat mengembangkan aspek sumber daya manusia, pengembangan kurikulum, kualitas sarana sumber belajar, metode dan media pembelajaran. Aspek realitas eksternal sekolah adalah ledakan jumlah lulusan sekolah yang mampu bersaing eksternal sekolah serta dapat mengelola dampak positif dan negatif teknologi bagi perkembangan jiwa warga sekolah. 
Hal tersebut cacatan penting harus diselesaikan oleh kepala sekolah. Beberapa lembaga pendidikan berusaha merekut jumlah peserta didik tanpa disertai dengan standar tertentu menjadi peserta lembaga tersebut sehingga berdampak negatif proses pembelajaran.

Setiap organisasi sekolah mempunyai struktur kelembagaan yang bertugas memandu dan mendorong tugas-tugas kepala sekolah, wakil kepela sekolah dan para guru. Struktur itu seyogyanya mampu merespon realitas internal dan realitas eksternal sekolah. Struktur sekolah mempunyai peran penting untuk membatasi hak dan kewajiban setiap warga sekolah dalam menjalankan tugas sesuai dengan bidang profesinya. Struktur itu mestinya mempunyai peran memandu batasbatas wilayah pekerjaan setiap warga sekolah dan memfasilitasi kebutuhan-kebutuhan pelayanan kepada orang tua peserta didik.

\section{Kontruksi nilai-nilai di organisasi sekolah}

Nilai-nilai organisasi secara spesifik adalah keyakinan yang dipegang teguh seseorang atau kelompok orang mengenai tindakan atau tujuan yang seharusnya dijadikan landasan atau identitas organisasi dalam menjalankan aktivitas industry noble, menetapkan tujuan-tujuan organisasi atau memilih tindakan yang patut dijalankan di antara beberapa alternatif yang ada (Cathy Enz, 1986: 27). Nilai-nilai (values) adalah keyakinan abadi (enduring belief) yang dipilih seseorang atau sekelompok orang dalam organisasi sekola sebagai dasar untuk melakukan suatu kegiatan tertentu (mode of conduct) atau sebagai tujuan akhir tindakannya (end state of existence).

Nilai dapat dibedakan menjadi dua yaitu terminal dan instrumental values (Rokeach, 1973). Sementara menurut Robin William Jr. menjelaskan bahwa values bukan hanya berfungsi sebagai kriteria atau standar untuk menjelaskan tindakan tetapi juga berfungsi sebagai kriteria atau standar untuk melakukan penilaian, menentukan pilihan, bersikap, beragumentasi maupun menilai performance.

Secara keseluruhan nilai dan kategori nilai temuan penelitian dari dua kasus penelitian di SD Unggulan Al-Ya'lu Malang dan SDI Alam Bilingual Surya Buana Malang dapat dirangkum dalam tabel berikut ini: 
Tabel: Nilai Dan Kategori Nilai Temuan Penelitian

\begin{tabular}{|ll|l|l|}
\hline \multicolumn{1}{|c|}{ Nilai } & \multicolumn{1}{|c|}{ Status } & \multicolumn{1}{|c|}{ Sumber } \\
\hline 1. & Unggul/cita-cita tinggi & Terminal & Tuhan/Manusia \\
2. & Keteladanan & Instrumen & Tuhan/Manusia \\
3. & Profesional & Terminal & Manusia \\
4. & Keteguhan & Terminal & Manusia \\
5. & Ukhuwah Islamiyah & Terminal & Manusia \\
6. & Kompetisi & Terminal & Tuhan/Manusia \\
7. & Amanah & Terminal & Tuhan/Manusia \\
8. & Penghargaan & Terminal & Manusia \\
9. & Wakaf diri & & \\
\hline
\end{tabular}

Dari uraian nilai-nilai organisasi sekolah dasar yang berbasis Islam. Nilai-nilai di atas memahamkan kepada jiwa guru dan pegawai kantor. Pemahaman nilai-nilai yang kuat dijadikan kepala sekolah untuk menggerakkan para guru dan pegawai agar mengartikulasikan visi sesuai dengan bidang mereka masing-masing yang mampu mendorong warga sekolah berubah secara terus-menerus kearah lebih baik. Pendapat tidak jauh berbeda bahwa nilai amanah, disiplin, dan cita merupakan gambaran pemimpin sekolah membangun jiwa visioner. Jiwa visioner warga sekolah merupakan nilai-nilai bersama. Hal ini senada pendapat Tan bahwa nilai nilai bersama yang dapat mengembangkan budaya berprestasi (Victor, S.L.,2002: 31). Nilai-nilai bersama yang dapat mewujudkan visi sekolah adalah (1) berorientasi pada hasil; (2) pelayanan kepada pelanggan tinggi; (3) inovasi; (4) kejujuran; (5) penghargaan; (6) respon terhadap perubahan; (7) akuntabilitas; dan (8) keinginan besar.

Nilai-nilai bersama budaya berprestasi dalam organisasi tersebut digambarkan oleh Victor Tan, seperti tampak pada gambar berikut ini. 


\section{Gambar : Nilai Bersama Budaya Berprestasi}

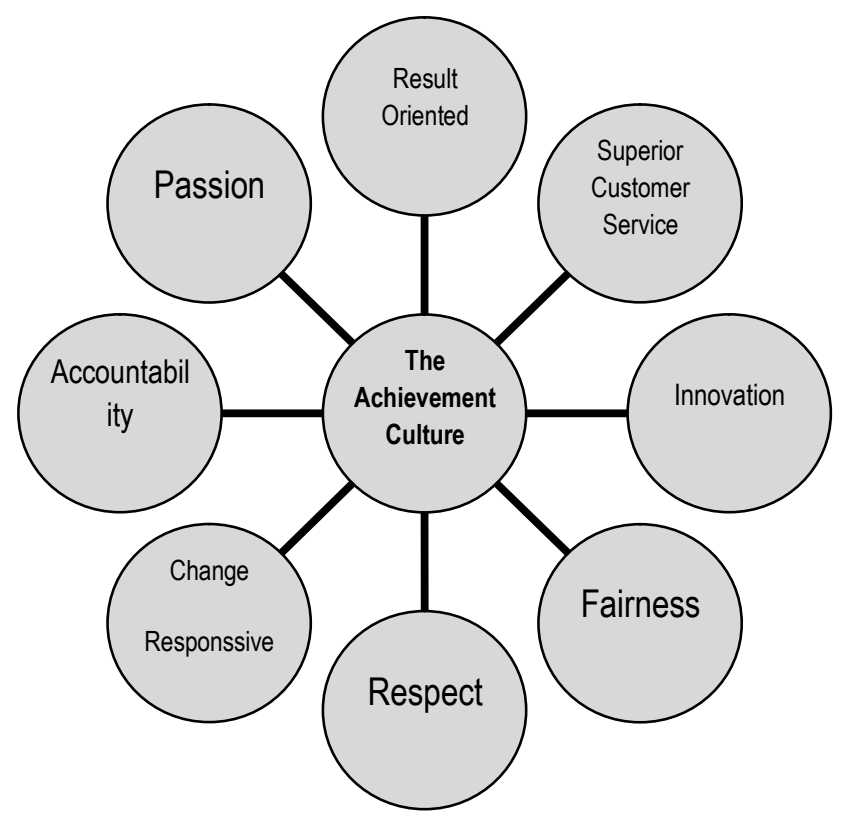

Untuk mencapai budaya berprestasi (achievement culture) merupakan tipe budaya yang mendorong dan menghargai kinerja orang. Pemimpin perlu menyebutkan dan mengkomunikasikan dengan jelas visi dan tujuan organisasi kepada semua tingkatan staf dalam organisasi sekolah. Organisasi mempunyai sasaran yang terukur dan menggunakan orang yang akuntabel untuk mencapainya. Mereka mempunyai sistem penilaian yang transparan dan jujur, terikat erat dengan penghargaan berdasarkan kinerja.

Nilai-nilai organisasi sekolah di atas telah memiliki kekuatan dan mampu menghasilkan transformasi perilaku yang produktif dan profesional kepada guru dan pegawai kantor bertindak sesuai dengan harapan pemimpin sekolah. Nilai-nilai itu menggerakkan warga sekolah menuju visi yang dikehendaki sekolah. Nilai-nilai bersama di sekolah hakikatnya merupakan hasil dari insprirasi keteladanan pemimpin sekolah dalam memaknai ajaran Islam lebih harmoni, kuat dan sumber belajar pilihan yang luas yang menyebabkan tradisi lebih baik dari sebelumnya, sistem sekolah, dan visi yang dikembangkan. Hal ini menyebabkan saling mempengaruhi di antara kepala sekolah, 
wakil kepala sekolah, guru, dan pegawai kantor. Terjadilah sistem nilai sekolah yang selanjutnya ditranformasikan pada komunitas internal dan eksternal di dalam warga sekolah. Proses transformasi tersebut dengan metode; keteladanan, conditioning, pengarahan, pembiasaan, penugasan, dan juga menggunakan media; perkataan, perbuatan, tulisan, dan kenyataan.

Dalam konteks penelitian ini, pembentuk nilai-nilai dari SD Unggulan Al-Ya'lu Malang dan SDI Alam Bilingual Surya Buana Malang memiliki kecenderungan sama yakni bersumber dari nilai-nilai individu para pemimpin sekolah. Sedangkan nilai-nilai individu para pemimpin sekolah dilatarbelakangi oleh visi sekolah mereka. Namun, SDI Alam Bilingual Surya Buana Malang berusaha membangun sekolah berbasis kultural masyarakat di Malang. Hal itu tidak melupakan cita-cita dan filosofi sebagai pemandu jiwa yang dapat menggerakkan warga sekolah, pedoman inilah yang biasa disebut core values.

Temuan data empiris di atas diperkuat oleh hasil penelitian Edgar Schein, yang menuturkan bahwa pembentukan jiwa visioner tidak dapat dipisahkan oleh peran pemimpin sekolah, prosesnya mengikuti alur sebagai berikut:

Para pendiri dan pemimpin lainnya membawa serta satu set asumsi dasar, nilai-nilai, persepektif, artifak ke dalam organisasi dan menanamkannya kepada para bawahan; budaya muncul ketika para anggota organisasi berinteraksi satu sama lain untuk memecahkan masalah-masalah pokok organisasi yakni masalah integrasi internal dan adaptasi eksternal; secara perorangan, masing-masing anggota organisasi boleh jadi mejadi seorang pencipta budaya baru (culture creator) dengan mengembangkan berbagai cara untuk menyelesaikan persoalan-persoalan individual seperti persoalan identitas diri, kontrol, dan pemenuhan kebutuhan serta bagaimana agar bisa diterima oleh lingkungan organisasi yang diajarkan kepada generasi penerus (Schein,1983: 15).

Dengan demikian, dalam konteks temuan penelitian ini, perbedaan nilai diduga lebih disebabkan oleh perbedaan latar pendidikan pendiri sekolah. Hal ini menggugurkan tesis Robbins yang menuturkan bahwa dimensi yang tepat untuk melihat perbedaan nilai yang ditemukan utilitas atau attribute intensitas kebutuhannya (how important) utilitas pihak (komponen) warga (Stephen P., 1996: 130). 
Setiap organisasi sekolah memiliki nilai dan keyakinan yang menjadi rujukan dalam mengelola organisasinya. Nilai-nilai SD Unggulan Al-Ya'lu tercermin pada logo organisasi dalam gambar seorang ibu muslimah yang merangkul kedua putra dan putrinya. Hal ini tampak dalam aktivitas belajar-mengajar secara tertib di sekolah. Keyakinan kepemimpinan SD Unggulan Al-Ya'lu Malang nampak berusaha mewujudkan kata "Unggulan" dalam melakukan proses pembelajaran secara berkualitas dan menghasilkan karya yang dapat dikompetisikan. Setiap karya guru yang mendapatkan prestasi dapat penghargaan dari lembaga.

Kepala sekolah telah memaparkan membangun jiwa visioner karyawan SD Unggulan Al-Ya'lu yaitu nilai-nilai yang ditanamkan adalah keteladanan, profesional, dan kompetisi. Nilai-nilai itu telah diyakini dapat melahirkan keunggulan SD. Sisi lain kepala sekolah mengelola sumber emosional dan spiritual yang berupa nilai-nilai, keperpihakan, pelayanan yang maksimal dan aspirasi para guru dan pegawai kantor. Suatu pernyataan kepala sekolah yang memiliki jiwa pemimpin yang visioner harus mempunyai kepemimpinan diri yang merupakan dasar dari segala bentuk kepemimpinan.

Kepemimpinan diri adalah kemampuan menegakkan disiplin atas diri pribadi dan mendorong orang lain mengikuti visi sekolah. Hal ini berdampak pada keberanian dalam arti luas yang berarti berani untuk memiliki mimpi yang besar dan berani untuk melangkah menghadapi resiko yang akan menghadang. Hal ini diperkuat oleh wakil kepala sekolah kurikulum dan hubungan masyarakat berikut ini.

Nilai amanah adalah derajat tertinggi yang diberikan oleh yayasan. Nilai ini akan terwujud manakala kepemimpinan diri dimiliki orang-orang yang dipercaya menduduki jabatan tertentu di sekolah. Dan amanah yang diberikan oleh kepala sekolah adalah menjalankan pembangian yang diberikan, yang didasari loyalitas yang tinggi agar kepemimpinan dapat memfokuskan untuk mewujudkan visi sekolah.

Nilai amanah ditanamkan kepada para guru dan pegawai kantor di melalui berita acara kontrak kerja dan menjalankan kerja secara profesional karena setiap pekerjaan harus didasari sebagai profesi yang menuntut adanya ketaatan pada pemimpin dan mengabdikan diri ke lembaga secara utuh tanpa membagi dengan sekolah lain. 
Penjelasan di atas membenarkan pendapat kepala sekolah pentingnya nilai loyalitas dan nilai dedikasi yang termanifestasi ketaatan menjalankan profesi yang dapat melahirkan karya dan prestasi. Seorang pemimpin harus memberikan keteladanan dalam menanamkan nilai dedikasi dalam meningkatkan kualitas pendidikan formal secara terus-menerus. Pengembangan sumber daya manusia merujuk pada nilai-nilai yang terkandung pada Surat Al-A'laq menumbuhkan kesadaran bahwa keunggulan akan diperoleh jika warga sekolah bersedia belajar dan mendalami masalah-masalah yang menyebabkan dapat berkarya dan berprestasi. Kemampuan berkarya memberikan pengalaman tersendiri bagi setiap guru. Jiwa berkarya merupakan cermin guru yang bersedia mewujudkan visi pemimpin sekolah.

Hasil analisis peneliti di atas memperkuat bahwa nilai dapat mengorganisasi sumber daya manusia untuk menggerakkan roda organisasi sekolah. Kompetisi itu dapat menggerakkan perkembangan organisasi sekolah ke arah perubahan positif dan dinamis. Sebagaimana pendapat Robbins (1996: 9 , "An understanding of individual behavior begins with a review of the major psychological contributions to organizational behavior. We have subdivided these contributions under the following five concepts: values, attitudes, personality, perception, and learning". Pendapat Robbins itu memperjalas bahwa nilai memiliki prioritas utama dalam menggerakkan warga sekolah mengartikulasikan visi sekolah.

Nilai-nilai itu dapat menginspirasi para pendiri dan para guru SDI Alam Bilingual Surya Buana ini sangatlah tinggi, dengan nilai-nilai tersebut mereka mampu mewujudkan apa-apa yang ia mimpi-mimpikan. Perjuangan itulah banyak orang kagum dengan perkembangan yang dimiliki oleh lembaga ini. Selain mereka mempunyai nilai yang baik juga keyakinan mereka sangat kuat untuk meraih dan sekaligus mengantarkan SDI Alam Bilingual Surya Buana ini kepada yang sebenarnya yaitu "kemajuan" yang bisa dinikmati oleh banyak orang.

Keyakinan dapat dibedakan dari sikap dan nilai di mana keyakinan berisi pengetahuan atau ide-ide yang diterima sebagai sebuah kebenaran. Keyakinan dipandang sebagai konstrak kognitif umum yang dipegang para pemimpin sekolah SDI Alam Bilingual Surya Buana sebagai sesuatu yang benar. Sikap dan nilai mungkin juga mencakup komponen kognitif, tetapi hal tersebut tidak dilihat sebagai sebuah fakta atau kebenaran. Sebagai contoh, sikap juga meliputi sebuah aspek evaluasi yang menjadi 
bagian integral dari komponen orientasi kognitif orang tua, sebagai sebuah "sikap positif" atau "sikap negatif". Nilai, bentuk lain dari kognisi sosial orang dewasa, lebih mengacu pada tujuan jangka panjang yang dipegang orang tua untuk anak-anaknya daripada sebagai sebuah kebenaran. Nilai tampaknya lebih dekat hubungannya dengan hasil akhir seperti apa yang dikehendaki orang tua dari anaknya. Sementara itu, keyakinan berhubungan dengan bagaimana anak beralih dari satu level menuju level lain.

Sebagai pemimpin visioner, Kepala Sekolah SDI Alam Bilingual Surya Buana selalu menumbuhkan semangat perubahan secara terus menerus rasa kebanggaan terhadap lembaga pendidikan yang dipimpinnya. Pemimpin seperti itu berusaha memberikan apa yang terbaik, dan mewakahkan demi kepentingan lembaga yang dipimpinnya. Jiwa mewakafkan selalu tumbuh pada dirinya. Sebaliknya, semangat mendapatkan lebih, selalu dihindari. Selain itu, pemimpin visioner juga berjiwa pemersatu di antara para pimpinan, para guru, dan para karyawan SDI Alam Bilingual Surya Buana. Pemimpin visioner tidak saja memberikan petunjuk, pandangan, dan kebijakannya, tetapi juga kearifan dan empatinya. Maka orang-orang seperti inilah yang bisa disebut sebagai pemimpin visioner yaitu pemimpin yang selalu berpikir maju dan berpikir jauh ke depan.

Kepala SDI Alam Bilingual Surya Buana Malang telah mewakafkan waktu, pikiran, dan tenaga mewujudkan impian lembaga pendidikan Islam yang unggul dan wibawa. Kepala sekolah menggambarkan sosok pribadi secara utuh sehingga pribadinya dapat menjadi teladan bagi banyak pihak khususnya di kota Malang. Fakta sejarah tersebut melahirkan kepercayaan masyarakat terhadap lembaga tersebut. Kepemimpinan SDI telah mampu menyesesuaikan terhadap kebutuhan masyarakat. Kepemimpinan yang dimiliki oleh pimpinanan tersebut untuk mencapai keunggulan organisasi dalam bersaing dalam melayani keinginan pemakai jasa pelayanan pendidikan.

\section{Kesimpulan}

Organisasi sekolah merupakan unit sosial-budaya bertanggung jawab dalam penyelenggaraan sumber daya manusia yang berjenjang dan berkualitas yang dapat merespon kebutuhan pasar. Pasar pendidikan sangat dinamis dan terbuka meniscayakan kapasitas pengelolaan yang 
memenuhi kriteria ideal dan prinsipil. Kapasitas kepala sekolah mampu mendasari nilai-nilai instrumental dan nilai-nilai terminal serta tradisi positif berperan menggerakkan organisasi mekanik menuju organisasi organik.

Kepala sekolah merupakan fasilitator organisasi sekolah berperan membangun jiwa leader maupun jiwa manager. Jiwa tersebut melekat pada pribadi dan performa kepala sekolah. Setiap kepala sekolah bertugas menginspirasi kepada warga sekolah mempunyai jiwa leader dan manager. Dua jiwa itu dibutuhkan dalam membentuk kompetensi kepemimpinan dan kompetensi keteraturan kerja di organisasi sekolah. Sekolah sebagai wadah pembinaan perkembangan peserta didik membutuhkan performa warga sekolah dalam menggerakkan kinerja yang berkualitas tinggi.Tahapannya adalah kepemimpinan kepala sekolah yang mampu membaca hambatan menjadi peluang. Kapasitas itu menjadi penentu bagi seorang kepala sekolah dalam dinamika internal organisasi maupun eksternal organisasi sekolah.

\section{Daftar Pustaka}

Abu Dawud Sulaiman Ibnu al-Asyat al-Sajistami al-Azdiy, Sunan Abi Dawud, Indonesia: Maktabah Dahlan, tt.

Antonio, Muhammad Syafii . (2007).Muhammad SAW Super Leader dan Super Manager, Pro LM Centre, Jakarta.

Enz, Cathy. (1986).Power and Shared Values in the Corporate Culture, Michigan: UMI Research Press.

Jo Hatch, Mary. (1997). Organization Theory, Oxford University Press.

Hambali, Muh. (2012). Kepemimpinan Visioner (Studi Multi Kasus di SD Unggulan Al-Ya'lu Malang dan SDI Alam Bilingual Surya Buana Malang), Jurnal Madrasah volume 5 No. 1 Juli-Desember UIN Maliki Press Malang.

Harefa, Andrias. (2002). Menjadi manusia Pembelajar, Kompas, Jakarta, 2000

Gary Yukl, Leadership in Organizations, Prentice-Hall International, Inc, New Jersey.

Nanus, Burt.(1989).The Leader's Edge: The Seven Keys to Leadership in a Turbulent World, Contemporary Books, New York. 
P. Kotter, John. (1994). Leadership-dialog with 100 Top Leader, The Leadership Press.

Pidarta, Made .(1995). Peranan Kepala sekolah pada Pendidikan Dasar, PT Gramedia Widiasarana Indonesia, Jakarta.

Yukl, Gary. (1981). Leadership in Organizations, Prentice-Hall International, New Jersey.

R.M. Steers, G.R. Ungson, R.T. Mowday. (1985). Managing Effective Organizations, Kent Publishing Company: A Division of Wadsworth,Inc, Boston Massachusetts.

Robbins, Stephen. (1996).Organizational Behavior: Concept, Controversies, and Applications, Prentice-Hall International, Inc., Upper Saddle River New Jersey.

Yukl, Gary .(1981).Leadership in Organizations, Prentice-Hall International, New Jersey.

website SD Unggulan Al-Ya'lu yang beralamat, www.al-yaklu.com

Quiqley, Joseph V. (1993). Vision: How Leaders Develop it, Share it, and Sustain it, New York: McGraw-Hill.

Sallis, Edward. (1993). Total Quality Management in Education, New Jersey: Prentice-Hal. Inc.

Q.S. 2 Surat Al-Baqarah (Sapi Betina) Ayat 30)

Nanus, Burt (2001).Visionary, Leadership:creating a compelling sense of direction for your organization, PT Prenhallindo, terj. Frederik Ruma, Jakarta.

Kasali, Rhenald .(2007).Change, Cet. 9, PT. Gramedia, Jakarta. .(2007) . Re-Code Your Change DNA (Membebaskan Belenggu-belenggu untuk Meraih Keberanian dan Keberhasilan dalam Pembaharuan), PT Gramedia Pustaka Utama, Jakarta.

Stephen Robbins, Organizational Behavior: Concept, Controversies, and Applications, Prentice-Hall International, Inc., Upper Saddle River New Jersey.

Terry, Robert W.. (1990).Kepemimpinan Autentik (Alih bahasa: Hari Suminto), Interaksara, Batam Center.

William A. Cohen, The Art of the Leader, Simon dan Schuster.

Antonio, Muhammad Syafii. (2007). Muhammad SAW Super Leader dan 
Super Manager, Pro LM Centre, Jakarta.

Bernard M. Bass, Stogdill's Handbook of Leadership: A Survey of Theory and Research. New York: The Free Press, A Division of Macmillan Publishing Co., Inc, 1981.

W. Bennis \& R. Townsend.(1995). Reinventing Leadership. New York: William Morrow and Company. Inc.

Rokeach, Milton. (1973).The Nature of Human Values, New York: The Free Press.

Tan, Victor, S.L., (2002). Changing Your Corporate Culture, Times Books International, Singapore.

Schein, Edgar .(1983).The Role of The Founder in Creating Organizational Culture, in Organizational Dynamic.

Robbins, Stephen P., (1996). Organizational Behavior (5 th) Prentice-Hall, Inc., New Jersey. 
